\title{
Flying High or Lying Low?
}

\author{
The Moral Economy of Young Women in Higher Education in \\ Punjab, India
}

\author{
Navtej K. Purewal and Manpreet K. Gill
}

\begin{abstract}
This chapter explores young women's participation in higher education as a reflection of changes and challenges to the moral economy currently taking place in the Indian state of Punjab. With its renowned capitalist agricultural development as well as skewed sex ratios against females, we highlight how the metaphorical liking of girls and young women as 'paraya dhan' (others' property) outward bound from the natal 'nest' highlights the deepening and extending role of gendered patriarchal norms making women's education a potential risk to the moral economy of society. Thus, the moral panic surrounding the sex ratio and 'scarce women' in Punjab exists within a paradoxically broader moral economy in which potentially threatening impacts of women's higher education participation to the patriarchal social order are measured up against a deeply patriarchal social and economic base of Punjabi society.
\end{abstract}

Keywords: Punjab, Higher Education, Gender

This study builds upon evidence from secondary data sets which point to trends of changing participation patterns in higher education. While at a glance an increase in women's enrollment in higher education might be interpreted to reflect a rising value being placed on women's education, our qualitative assessment of this increase reveals a more complex picture in which women's education has become incorporated into broader aspirations around migration and marriage which are shaping the moral economy and its gendered value, with new and oftentimes more restricting cultural values being associated with women's educational pursuits. 
In: Sachdeva, Vivek and Pradhan, Queeny and Venugopalan, Anu, (eds.), Identities in South Asia: Conflicts and Assertions. New Delhi:Routledge.

Accepted version downloaded from SOAS Research Online: http://eprints.soas.ac.uk/25118

\section{Introduction}

The college or university campus has provided a readymade set for countless Indian films in showing storylines in which young men and young women intermingle and pursue academic and personal aspirations on the oasis-like campuses in these cinematic depictions. While the fantasy of film accentuates the liminality of college-going as a time of opportunities for freedom and youth romance as a precursor to familial obligation, marriage and working life, film fantasy is not so distantly removed from the experiences of young women and men who attend college and university. The dreams, fantasies, and aspirations that college-going represents at this age are universal. It is their symbolism and links to social and economic lived realities which we are concerned with and will be exploring in this chapter.

In India, the picture of the expansion of higher education shows that the demand for places in higher education institutions is increasing but that enrolment trends are gendered. The total gross enrollment in higher education in India is 19.4 percent, while it is 20.8 percent for males and 17.9 percent for females. While state-wise data show evidence of higher ratios of female enrollment in states such as U.P., Meghalaya, Himachal Pradesh and Kerala, the focus of our study is on the northwest state of Punjab where the differential in gross enrollment ratio shows 23.6 percent male and 14.5 percent female GER respectively, one of the highest gaps in India from the available state-wise data. While higher education discursively presents emancipatory potentials for young women through professional training and career paths, this study finds that any examination of enrollment and attendance must be viewed regarding how education is socially embedded. The family, in particular, regulates and values women's education through strategic decision-making, thus presenting pressures for women to not necessarily 'fly high' for personal motivations, but to navigate broader collective family attitudes and goals. While the gender impacts of the green revolution's capitalist agriculture on Punjab in the 1970s were recognized by Sharma (1980) as withdrawing women of land-owning families in particular from the public sphere as a sign of status, our exploration of women's higher education in the contemporary context of Punjab shows that the regulation of women's mobility as a sign of status and respectability has continued through the subsequent decades.

The global context of higher education attainment highlights the new meanings being attached to women's education as a tool for social mobility through marriage alliances and global migration as this relates to their families' aspirational desires. The evidence of more 
women pursuing higher education shows how education as a principle is being promoted on the grounds of uplifting women in encouraging them to "fly high" according to aspirational and globalising discourses. Meanwhile, the perception of young women's education by parents continues to circulate as a threat to the social order in which young women are encouraged to "lie low". One might also assume that "flying high" refers to either or both the aspirations to achieve and the desire to migrate abroad. In examining this metaphor, the paper draws upon Bourdieu's logic in exploring how the gender context of the Punjabi household is engaging with the heightened participation of young women in higher education showing how the objective logic exists as an ideal is shaping women's educational experience, attainment and outcomes. The paper will argue that higher education institutions are promoting education for women within this objective logic resulting in a mixed picture of raising young women's aspirations while simultaneously containing them.

\section{The Logic of Practice: The Moral Economy of Young Women and Higher Education in Punjab}

Punjab is associated with agriculture and, as such, has been popularly coined as the "breadbasket of India." Studies of the development of capitalist agriculture and its socioeconomic impacts have charted the transformations to social and class relations resulting from the Green Revolution strategy for agricultural growth through mechanisation, chemical inputs, and new forms of loans for financing investment for farmers (Byres 1983; Leaf 1984; Frankel 1971). However, as Bhalla (2004) states, "Punjab today presents a paradox... The state boasts of one of the highest per capita incomes in India... but the number of girls has shrunk alarmingly." The moral panic of the sex ratio constitutes a significant and pervasive public discourse in Punjab. The campaigns have been carried out in the state to mete out the 'culprits' of sex selective abortions and to 'discipline the sex ratio' through both criminalisation of sex selection and incentives to uplift the status of the girl child (Purewal 2014, 2018). The scarce women scenario in Punjab has seen its inclusion in India's 'kurhi maru' list of states identified by the central government's tracking of sex ratios (see Table 5.1). 
In: Sachdeva, Vivek and Pradhan, Queeny and Venugopalan, Anu, (eds.), Identities in South Asia: Conflicts and Assertions. New Delhi: Routledge.

Table 5.1Rank-Wise Per Capita Income and Sex Ratio across the States of India

\begin{tabular}{|c|c|c|c|c|c|c|c|c|c|c|c|c|}
\hline \multirow[t]{2}{*}{ STATE } & \multicolumn{6}{|c|}{ Per Capita Income } & \multicolumn{6}{|c|}{ Sex Ratio } \\
\hline & 1961 & 1971 & 1981 & 1991 & 2001 & 2011 & 1961 & 1971 & 1981 & 1991 & 2001 & 2011 \\
\hline A.P. & 9 & 16 & 18 & 13 & 10 & 13 & 9 & 7 & 5 & 5 & 4 & 3 \\
\hline ARUN. P. & NA & 20 & 22 & 14 & 18 & 12 & 23 & 28 & 27 & 28 & 24 & 17 \\
\hline ASSAM & 6 & 7 & 8 & 10 & 21 & 24 & 26 & 20 & 21 & 15 & 14 & 14 \\
\hline BIHAR & 16 & 21 & 23 & 23 & 28 & 28 & 6 & 9 & 11 & 21 & 20 & 23 \\
\hline JHARKHAND & NA & NA & NA & NA & 26 & 23 & 10 & 12 & 14 & 16 & 13 & 16 \\
\hline GOA & NA & 6 & 1 & 1 & 1 & 2 & 1 & 4 & 6 & 7 & 11 & 9 \\
\hline GUJARAT & 4 & 9 & 10 & 9 & 9 & 5 & 13 & 16 & 13 & 13 & 19 & 22 \\
\hline HARYANA & 5 & 1 & 3 & 3 & 3 & 3 & 27 & 25 & 25 & 27 & 28 & 28 \\
\hline H.P & NA & 4 & 5 & 5 & 5 & 10 & 14 & 8 & 7 & 3 & 8 & 11 \\
\hline $\mathrm{J} \& \mathrm{~K}$ & 10 & 5 & 4 & 11 & 19 & 20 & 24 & 22 & 22 & 22 & 25 & 27 \\
\hline KARNATAKA & 7 & 14 & 15 & 16 & 8 & 11 & 11 & 10 & 9 & 8 & 9 & 10 \\
\hline KERALA & 11 & 3 & 7 & 7 & 7 & 9 & 2 & 1 & 1 & 1 & 1 & 1 \\
\hline M.P & 12 & 15 & 17 & 19 & 23 & 25 & 18 & 18 & 17 & 19 & 21 & 19 \\
\hline $\begin{array}{l}\text { CHHATTISGH } \\
\text { AR }\end{array}$ & NA & NA & NA & NA & 24 & 21 & 5 & 2 & 2 & 2 & 2 & 5 \\
\hline $\begin{array}{l}\text { MAHARASHT } \\
\text { RA }\end{array}$ & 1 & 8 & 6 & 4 & 4 & 4 & 16 & 17 & 15 & 14 & 18 & 20 \\
\hline MANIPUR & 17 & 18 & 14 & 18 & 22 & 26 & 3 & 5 & 8 & 9 & 5 & 4 \\
\hline MEGHALAYA & NA & NA & 11 & 12 & 17 & 15 & 15 & 13 & 10 & 10 & 6 & 6 \\
\hline MIZORAM & NA & NA & NA & NA & 11 & 16 & 4 & 11 & 18 & 17 & 15 & 8 \\
\hline NAGALAND & NA & NA & 9 & 6 & 13 & 14 & 19 & 24 & 26 & 23 & 22 & 18 \\
\hline ORISSA & 15 & 12 & 16 & 22 & 25 & 22 & 7 & 3 & 3 & 6 & 7 & 7 \\
\hline PUNJAB & 3 & 2 & 2 & 2 & 2 & 8 & 28 & 26 & 24 & 24 & 26 & 25 \\
\hline RAJASTHAN & 8 & 11 & 11 & 15 & 20 & 19 & 20 & 19 & 19 & 20 & 17 & 21 \\
\hline SIKKIM & NA & NA & NA & NA & 14 & 1 & 22 & 27 & 28 & 25 & 27 & 26 \\
\hline TAMIL NADU & NA & 10 & 13 & 8 & 6 & 6 & 8 & 6 & 4 & 4 & 3 & 2 \\
\hline TRIPURA & 14 & 19 & 19 & 20 & 15 & 18 & 17 & 14 & 12 & 11 & 12 & 13 \\
\hline U.P. & 13 & 17 & 20 & 21 & 27 & 27 & 12 & 15 & 16 & 12 & 10 & 12 \\
\hline $\begin{array}{l}\text { UTTARAKHA } \\
\text { ND }\end{array}$ & NA & NA & NA & NA & 16 & 7 & 21 & 23 & 23 & 26 & 23 & 24 \\
\hline $\begin{array}{l}\text { WEST } \\
\text { BENGAL }\end{array}$ & 2 & 13 & 12 & 17 & 12 & 17 & 25 & 21 & 20 & 18 & 16 & 15 \\
\hline
\end{tabular}


Table 5.1 highlights the profile of the state of Punjab in its high rank regarding per capita income since 1961 and its near bottom ranking in comparison to other Indian states in terms of the sex ratio. As can be seen in the table, there is an inverse relationship in Punjab between per capita income and sex ratio which has further been explored by some in terms of a 'parity effect' seeing an intensification of male bias despite decreasing rates of fertility (Das Gupta 1995 and 1997) and by others in terms of how masculinist models of social organization and economic growth have historically led to deepened gender inequalities (Oldenburg 2002; Purewal 2010). Punjab thus provides a context in which to explore these multiple facets and outcomes of patriarchal and masculinist development resulting in 'scarce women' and 'surplus men', the lens through which we now will analyse women's presence in higher education.

The gendered dimension to the agricultural base shapes how the education of boys and girls is viewed under gender norms and ideals. While landless and poorer families are unlikely to send their male or female children to colleges out of economic necessity for their labour contributions to the household, landed and more privileged families in the region have been known to withhold their daughters from further education beyond primary schooling due to heightened regulation of girls' mobility and codes of humility and honour which can be viewed as compromised by girls' mobility in the public sphere (Mandelbaum 1988). Sen Gupta and Guha (2002) argue that while parental education, income and occupation have the strongest impact on girls' schooling opportunities and attainments, daughters of agricultural families have the lowest participation at higher levels of education. However, landowning families, because of land, are also known to invest in their daughters' education and not in their son's education, to keep them in agriculture (Heyer, this volume). While the material base of agricultural families posits girls at a distinctive disadvantage within this context of decision-making associated with education, the post-Green Revolution context of Punjab is seeing immense changes to rural sensibilities, requiring more qualitative assessment of this evolving picture.

The moral economy of peasant societies require customs and social 'norms' to survive, as systems which are governed by mutuality within social networks of economic actors and social units. (Scott 1977). In this respect, the moral economy of the Punjab rural household operates as a system of surveillance of women's mobility and their access to public space due to women's necessary compliance with kinship custom and arrangements (Purewal and 
In: Sachdeva, Vivek and Pradhan, Queeny and Venugopalan, Anu, (eds.), Identities in South Asia: Conflicts and Assertions. New Delhi: Routledge.

Hashmi 2014). It is here that we apply Bourdieu's (1992) thesis around the objective logic of the household within this moral economy of insecurity. We highlight that young women venturing into the public domain is often perceived as a risk-invoking act. Thus, the objective logic of the rural Punjabi household in the decision-making processes around young women's access to higher education is shaped by the symbolic function of female education within this moral economy of 'scarce women' in the forms of heightened moral policing of young women's movements as well as of women's higher education as an opportunity or hindrance for family-building strategies. Bourdieu's focus upon the symbolic function of education is particularly useful for understanding how a discriminatory logic against young women's education exists alongside a strategising use of women's education for wider goals. Where education can serve these collective goals, young women are encouraged to "fly high", but where education presents threats to the patriarchal status quo by providing tools for women to challenge or question the status quo, they are encouraged to "lie low" in order to preserve cultural gender norms which constitute the practical logic informing the 'habitus.'

Our focus on the rural context of Punjab exhibits how the household unit acts as a site where decision-making, as well as discrimination, exist within its walls. The domestic mode of production, as highlighted by materialist feminists, points to the complex economic, social and cultural dynamics of the household stemming from the economic base of patrimony, gifts, inheritance, power and hierarchies of status, and entitlements within the family (Delphy 1988). Diane Leonard's translated edition of Delphy's (1984) book Close to Home uses the rural context of France as a means of examining the significance of the family as a nonmarket sector of the economy in which agricultural families' identity and livelihood is centred upon land and inheritance through male heirs, and this inheritance is not doled out equally. While sons are given land and property in their inheritance, daughters are given gifts or dowries which require them to marry and exist non-autonomously, thus entrenching them within the patriarchal structures of not only their natal family but also their marital family. Leonard's (2000) exploration of the sociology of children raises further questions about the position of children within family structures regarding sibling and generational relationships in which daughters' entitlements are undermined by their circumscribed position as noninheriting members of the household unit. Feminist economists have probably contributed to the exploration of not only equality of opportunities but shifted the lens towards reproductive and productive labour and the equality of outcomes (Berik et al 2009; Elson 1994; Chant 
In: Sachdeva, Vivek and Pradhan, Queeny and Venugopalan, Anu, (eds.), Identities in South Asia: Conflicts and Assertions. New Delhi:Routledge.

2011). Croll (2002) similarly highlights the structural position of girls vis-à-vis the family which is culturally embedded and has resulted in the sex ratio outcomes of discrimination against girl children. The material base of the household in deeming entitlements through patrimony across a range of contexts are significant in understanding the position of girls in the family where decisions around education are made.

The household unit is thus based upon gendered differentiation which Delphy (1984) argues places the male patriarch at the centre through his discretionary powers to bestow inheritance according to his choice and preference, instilling hierarchies of authority and entitlements. She extends this notion of inheritance beyond property to include social and cultural capital which, for our purposes, would consist of the opportunities to access education. The negotiated hierarchies of gender through women's power must also be understood in terms of how the patriarchal family is not comprised of merely male authority but also of both women's complicity and active participation (Kandiyoti 1988). Applying this to the Indian context, Agarwal (1994), whose analysis of the structural dimensions of the household unit, utilises similar tools of understanding differential entitlements and gendered outcomes of systems of inheritance which create systemic barriers for women, explaining the resistance to women's access to property through the biased attitudes and practices against women's economic rights which argue that "endowing a daughter with land is seen by the natal family as bringing little reciprocal benefit, and any land inherited by her as lost to the family..." (2003: 204). Women's access to education and the understandings of the benefits (or risks) of investing in daughters' education must be situated within this a framework which considers not only the cultural attitudes towards gender but also the economic base which measures considerations around investments and benefits. This moral economy of higher education is gendered and informs our analysis here.

While the human capital discourse on girls' and women's literacy envisages a liberating effect of education on women's and families' lives (Colclough 1982), our analysis aligns with Kapadia's (2002) argument that the orientation of development processes is the cause for worsening status of women and declining sex ratios. The penetration of capitalism has resulted in what both Bhalla (2004) and Kapadia (2002) have characterised as a paradox of development. On the one hand, the household unit is becoming increasingly dependent on the domestic mode of production requiring women's continuing focus on the domestic, 
household sphere while, on the other hand, the marketisation of education presenting 'choices' to parents of girls as part of a broad schema of concerns laden with cultural values, rationalising assessments of returns, normative gender ideals and the domestic mode of production. These concerns constitute the gendered nature of the material relations of the family which are being challenged and reworked through the objective logic discussed earlier. It is these concerns regarding the domestic mode of production which is shaping girls' opportunities for being educated, and choices become more narrow as they progress to secondary and then higher education. However, the picture is not as simple as this. While education is becoming commodified, the value of education within a society which places so much emphasis on kinship relations is also affecting women's access to education in evolving ways. Education can also present opportunities for families for whom social mobility and migration within the global circuits of settlement and 'arranged' marriages are taking place. In this light, the local market of education can be understood through the demand for skills in terms of how, for instance, English-language and I.T. course offer new dimensions to how women can access education for ends tied to both individual aspirations as well as collective goals of the family. Higher education, thus, is expanding in subjects related to professional degrees such as medicine, engineering and law, but also other subjects which are deemed suitable, less ambitious, and thus 'respectable' for young women to pursue and to still be rendered marriageable, or, as we have connoted: 'lying low'. As our qualitative material will highlight, the values which are comprised by kinship concerns and common family strategies are being routed through the educational system in which young women's aspirations are simultaneously raised through higher education while also systematically curbed through the educational experience.

The higher education data from the Punjab Statistical abstract 2011-12 indicates that while there has been an increase in girls' share of enrolment since the 1990s in some courses (B.A, B.SC, M.A.) (Table 5.2), there are still more male students enrolled than girls in Engineering, Medicine and Architecture (Table 5.3). 
In: Sachdeva, Vivek and Pradhan, Queeny and Venugopalan, Anu, (eds.), Identities in South Asia: Conflicts and Assertions. New Delhi:Routledge.

Table 5.2 Percentage of Students by Gender Enrolled at Undergraduate Level in Punjab

\begin{tabular}{|c|c|c|c|c|c|c|}
\hline \multirow[b]{2}{*}{ Year } & \multicolumn{2}{|c|}{ B.A/B.A. (Hons.) } & \multicolumn{2}{|c|}{ B.Sc/B.Sc (Hons.) } & \multirow{2}{*}{\begin{tabular}{|l} 
B.Com/B.Com. \\
(Hons.)
\end{tabular}} & \multirow[b]{2}{*}{ Girls } \\
\hline & Boys & Girls & Boys & Girls & & \\
\hline 1980 & 54.75 & 45.25 & 69.62 & 30.38 & 94.09 & 5.91 \\
\hline 1990 & 43.98 & 56.02 & 53.73 & 46.27 & 68.69 & 31.31 \\
\hline 2000 & 45.61 & 54.39 & 46.24 & 53.76 & 53.50 & 46.50 \\
\hline 2008 & 42.92 & 57.075 & 31.58 & 68.42 & 50.08 & 49.92 \\
\hline 2009 & 41.69 & 58.31 & 30.74 & 69.26 & 51.25 & 48.75 \\
\hline 2010 & 42.30 & 57.70 & 30.60 & 69.40 & 50.25 & 49.75 \\
\hline 2011 & 46.18 & 53.82 & 29.01 & 70.99 & 45.98 & 54.02 \\
\hline
\end{tabular}

Source:Punjab Statistical Abstract 2011-12

Table 5.3 Percentage of Students by Gender Enrolled in Selected Subjects in Punjab

\begin{tabular}{|c|c|c|c|c|c|c|}
\hline & \multicolumn{2}{|c|}{ B.E./B.Sc.(Eng.) } & \multicolumn{2}{|c|}{ M.B.B.S } & \multicolumn{2}{|r|}{ B.Ed. } \\
\hline Year & Boys & Girls & Boys & Girls & Boys & Girls \\
\hline 1980 & 98.18 & 1.82 & 73.51 & 26.49 & 37.40 & 62.60 \\
\hline 1990 & 92.04 & 7.96 & 55.08 & 41.56 & 30.98 & 69.02 \\
\hline 2000 & 81.53 & 18.47 & 52.81 & 47.19 & 29.42 & 70.58 \\
\hline
\end{tabular}




\begin{tabular}{|l|l|l|l|l|l|l|}
\hline 2008 & & & & & & \\
\\
\hline 2009 & 78.22 & 21.78 & 49.96 & 49.38 & 26.48 & 73.52 \\
\hline & & & & & & \\
2010 & 74.62 & 25.38 & 50.81 & 49.19 & 17.48 & 82.52 \\
\hline & & & & & & \\
2011 & 73.98 & 25.02 & 45.86 & 37.17 & 17.48 & 82.52 \\
\hline
\end{tabular}

Source: Punjab Statistical Abstract 2011-12

While the above two tables show an increasing rate of women's participation in higher education by women, this is also subject-specific. Further to this, when we delved into these findings on a qualitative level, we found that women pursuing higher education negotiate a highly gendered terrain of parental and extended family discretion with regards to whether or not the opportunities to continue higher education should be awarded to them by their families. Thus, not only is the decision to go to college or university shaped by economic considerations (returns of the investment of education in light of conventions around women's imminent departure to their marital homes) but also culturally shaped gendered ones which deem girls' and young women's mobility in the public sphere a risk to her humility and the family's honour and respect.

\section{Methods}

This study draws upon the trends of increased participation and subject-specific areas of representation of women in higher education as identified in the data sets of the University Grants Commission (UGC) and state government of Punjab Statistical Abstract (Tables 5.2 and 5.3). While the juxtaposition of the sex ratio with per capita income for the state highlights an inverse relationship or a paradox, women's education presents a slightly less straightforward picture. We intend to examine this increasing participation of women in higher education and to pursue questions around whether or not this represents a reversal of discrimination against girls and women and what these trends might be reflecting about more extensive socio-economic developments in terms of how women's status relates to education. 

Asia: Conflicts and Assertions. New Delhi:Routledge.

Our study is based on sites selected from two districts in Punjab: Moga and Jalandhar. The context of the sex ratio in Punjab and its districts can be seen in Table5. 4 where the sex ratio for Moga and Jalandhar is 893 and 915, respectively.

Table 5.4 Sex Ratio in the Districts of Punjab

\begin{tabular}{|l|l|l|l|l|l|l|l|}
\hline Districts & $\mathbf{1 9 5 1}$ & $\mathbf{1 9 6 1}$ & $\mathbf{1 9 7 1}$ & $\mathbf{1 9 8 1}$ & $\mathbf{1 9 9 1}$ & $\mathbf{2 0 0 1}$ & $\mathbf{2 0 1 1}$ \\
\hline Gurdaspur & 846 & 869 & 890 & 907 & 903 & 890 & 895 \\
\hline Amritsar & 841 & 854 & 856 & 871 & 873 & 871 & 889 \\
\hline Tarn Taran & NA & NA & NA & NA & NA & 887 & 900 \\
\hline Kapurthala & 880 & 886 & 889 & 898 & 896 & 888 & 912 \\
\hline Jalandhar & $\mathbf{8 5 7}$ & $\mathbf{8 6 7}$ & $\mathbf{8 8 3}$ & $\mathbf{8 9 0}$ & $\mathbf{8 9 7}$ & $\mathbf{8 8 7}$ & $\mathbf{9 1 5}$ \\
\hline Hoshiarpur & 877 & 902 & 899 & 919 & 924 & 935 & 961 \\
\hline Rupnagar & 812 & 812 & 854 & 862 & 870 & 889 & 915 \\
\hline Ludhiana & 852 & 856 & 848 & 860 & 844 & 824 & 873 \\
\hline Ferozepur & 835 & 840 & 876 & 884 & 895 & 885 & 893 \\
\hline Faridkot & 856 & 849 & 866 & 879 & 883 & 883 & 890 \\
\hline Muktsar & 862 & 846 & 863 & 885 & 880 & 891 & 896 \\
\hline Moga & $\mathbf{8 6 7}$ & $\mathbf{8 6 2}$ & $\mathbf{8 6 6}$ & $\mathbf{8 8 1}$ & $\mathbf{8 8 4}$ & $\mathbf{8 8 7}$ & $\mathbf{8 9 3}$ \\
\hline Bathinda & 839 & 834 & 851 & 861 & 884 & 870 & 868 \\
\hline Mansa & 824 & 830 & 852 & 869 & 873 & 879 & 883 \\
\hline Sangrur & 820 & 832 & 840 & 860 & 870 & 870 & 885 \\
\hline Barnala & NA & NA & NA & NA & NA & 907 & 876 \\
\hline Patiala & 809 & 831 & 850 & 870 & 881 & 875 & 891 \\
\hline Fatehgarh Sahib & 773 & 815 & 831 & 841 & 871 & 854 & 871 \\
\hline PUNJAB & $\mathbf{8 4 4}$ & $\mathbf{8 5 4}$ & $\mathbf{8 6 5}$ & $\mathbf{8 7 9}$ & $\mathbf{8 8 2}$ & $\mathbf{8 7 6}$ & $\mathbf{8 9 5}$ \\
\hline INDIA & $\mathbf{9 4 6}$ & $\mathbf{9 4 1}$ & $\mathbf{9 3 0}$ & $\mathbf{9 3 4}$ & $\mathbf{9 2 7}$ & $\mathbf{9 3 3}$ & $\mathbf{9 4 3}$ \\
\hline SOurce: Difecto & Cen & & & & \\
\hline
\end{tabular}

Source: Director, Census operations Punjab

In focusing on the objective logic of the moral economy of rural households with development, we chose to focus on sites in Moga and Jalandhar, both districts showing some evidence of improvement in the sex ratio. Coupled with a heightening presence of women in higher education in these two districts, we intended to explore the dynamics at play behind the data in terms of decision-making, attitudes towards women's mobility, and the value associated with women's education. We selected three colleges where six semi-structured interviews and nine focus groups were conducted between 2013-14 (Table 5.5). 
Table 5.5 Sampling of the qualitative study

\begin{tabular}{|l|l|l|}
\hline & Interviews & $\begin{array}{l}\text { Focus Group } \\
\text { Discussions }\end{array}$ \\
\hline Women's college & $\begin{array}{l}1 \text { teacher } \\
1 \text { principal }\end{array}$ & 2 (women-only) \\
\hline Co-ed college & 1 teacher & 1 (mixed) \\
Jalandhar & 1 principal & 2 (men only) \\
& 1 (mixed, teachers) \\
\hline Women's college & 1 principal & 2 (women-only) \\
Jalandhar & - & 1 (mixed) \\
\hline Parents & $\mathbf{6}$ & $\mathbf{9}$ \\
\hline Total & & \\
\hline
\end{tabular}

Source: Authors

The interviews included teachers, principals and young women, and focus groups were conducted with female and male college students, teachers, principals and parents. All of the interviews and focus group discussions were recorded, transcribed, and coded.

Our interest in employing qualitative methods in this study was to delve beneath the surface of the discourse around 'missing girls' and to develop an understanding of new meanings, changes, and responses that are emerging with respect to the statistical evidence showing increasing women's participation in higher education in a state of consistently masculine sex ratios. Therefore, our sample reflects our interest in exploring the attitudes and reflections of teachers, parents, principals, and, of course, students themselves. The remits drawn around young women's education in a context in which education is being promoted provided the central principle in directing our questions within the qualitative fieldwork in terms of how families, educational institutions, young men, and, young women are responding. These remits are reflected upon in the qualitative data through the recurrent themes and concerns which emerged from the coded material.

\section{Extending Patriarchy: The Threats of Young Women's Education}

The annual review for 2013 of one of the colleges focused upon in this study was entitled 'chirhiyaan da Chamba' (transl. flock of birds), using the metaphor of the 'flock' to signify the home or college environment as the protective space for young women. The bird is popularly referred to highlight girls as temporary in their parental homes before 'flying off' to their marital homes explicitly rooting the metaphor in the social 'norms' of the moral 
economy. Thus, by evoking the flock of birds metaphor, the college projected itself as providing a 'safe' environment much like the home where young women are 'looked after' during the important years between the stages of unmarried youth and marriage. This must be understood both in terms of the depiction of the college space as a 'safe' place for young women as well as an extension of the household's moral policing role into the public educational and institutional spheres. In an interview with the principal of this women's college, she states that there is reluctance from parents to send their daughters to college and situates this reluctance within concerns around respect, a generational exertion of authority, and a general lack of interest or commitment to women's education:

Yes, there is an improvement from before, but only by a small percentage. Only a few parents really value the education of girls... They don't see that a girl who studies won't just get married and move to their marital home but that her life will improve with the benefits that education brings to girls which they bring to themselves and their families. [interview, August 2012]

To 'really value' the education of girls, as the principal here highlights, means to forego the risks associated with having a daughter who might have difficulty in eventually finding a suitable marriage match. The 'norm' of marriage appeared throughout the FGDs and interviews as a primary concern often in conflict with the education of young women at higher levels. This principal went on to say that the risks associated with daughters' education extend further:

A lot of parents say that by going to college, their respect will be ruined. They think that by going to college, they are risking tainting the respect and honour of their families by coming into contact with boys at college. From being a principal, I have the experience of seeing that the biggest responsibility to encourage girls to attend college is mothers. The grandmother (paternal) of the girls has the most say in this matter because often she is jealous because she did not have the opportunities and that she thinks "why should these girls have the opportunities that we did not?" This is where the izzat factor comes in again and is used as an excuse for not sending girls to college. But more educated parents do not stop their girls in this way from attending college. They are more likely to support their girls in obtaining higher education.

It is within this understanding that the college utilises the flock of birds metaphor to highlight the college's commitment to showing its concerns for the safety of girls and of 
In: Sachdeva, Vivek and Pradhan, Queeny and Venugopalan, Anu, (eds.), Identities in South Asia: Conflicts and Assertions. New Delhi:Routledge.

maintaining the respect of their families. Thus, the patriarchal ethos is extended from the home to the college as a continuum in which young women are looked after first by parents and then by the college as a form of extended patriarchy.

While most parents and teachers reflected overtly upon the need to 'protect' girls as a duty of both family and college, the material base of gender relations is what informed how the value and threat of young women's education was being understood in terms of land, property, and the gendered relations of the household unit, influencing relationships with siblings, especially brothers.

As a male I.T. teacher commented: 'Boys don't like the idea of their sisters having rights to half of their share of any family property' (age 43). In direct response, a female science teacher commented in defence of the patriarchal unit. She situated girls attachment with their parents and siblings within the emotional ties and bonds which make daughters nondemanding entities within the economic realm of their natal household:

\footnotetext{
Parents give their daughters so much love that why would girls want to take any land? Parents go out of their way to educate their daughters. Their prayers and blessings for their brothers and parents are their biggest role. I only wish for my brother's happiness. I would never take my share. Boys have the duty of serving and looking after their parents, so it is their right.... Girls also don't ask about their parents. It's not necessary that girls should look after their parents only because they have some rights over property. If a daughter is needy, then help should be given. Otherwise, nothing needs to be given. We, women, believe that we have to have good relations with our brothers, so what's the need for land and property? (age 52).
}

The resistance from family members to permit girls to study backed by the moral policing of girls and young women framed most of the discussions around girls' experiences of education. The mother of a young woman who had recently completed her degree at the nearby college commented: 'My sons didn't want my daughter to continue studying, but we (my husband and I) ignored their complaints, and we made sure she completed her B.A. studies. Her Dad also supported me.'

One of the female colleges, also considered a 'safe' choice to send daughters to, was described by students: 'This college is near to our villages, and our parents don't want to send us to a co-ed college. When we are coming from home, boys tease and harass us so many parents don't send their daughters to study fearing this, especially in the villages.'

The underlying patriarchal framework which frames the worth of investing in daughters' education or taking the risk to send daughters to college within a context of moral 
In: Sachdeva, Vivek and Pradhan, Queeny and Venugopalan, Anu, (eds.), Identities in South Asia: Conflicts and Assertions. New Delhi:Routledge.

policing is necessarily an issue of women's autonomy which extends beyond the idea of having access to education into a comparative notion of rights relative to their male kin. Thus, the flock of birds metaphor which operates on an emotional as well as economic level is simultaneously bolstered by the parayadhan (transl. 'others' property) depiction, in which women are married off and leave their natal homes to become a part of their in-laws' home, thus having no claims to parental property or inheritance. This presents the foundation to how the young women in our study are navigating the gendered and mediated access to education. A teacher in one of the colleges expressed this unequivocally by stating that not only are girls paraya dhan but sons, regardless of anything, are one's own. 'Girls become other people's property [paraya dhan] when they are married because sons are the ones who will be living with their parents. Whether they are alcoholics or taking drugs, a son belongs to his parents. Girls become a part of their in-laws family.'

The young women in this study voiced some criticisms of this framing in an emerging determination to prove to family members that they can achieve, despite the characterisations of their weakness and vulnerability. One young woman vocalised this by stating: 'Girls can bring respect and pride to their parents by studying, and we should show them that girls can also do many things in spite of people continually stopping them.' In a focus group in one of the co-educational colleges, a young man highlighted an underlying tension around the question of the limits and threats of women's education when he commented on his preference regarding the ideal type of woman he would like to marry: 'She should be simple but educated, to educate the children. But she shouldn't have a job. Because if she works outside of the house, who will manage the household? Who will educate the children? Our parents have worked all their lives, so if she goes out, then who will look after my parents. I want to give them relief.'

Thus, as this quote expresses, young women's education, while being necessary for the progress of the family, should be limited for the household to benefit in terms of her nurturing and caring functions, an embedded part of the moral economy, rather than as a professional or an income-generator. This notion is what lies at the crux of our title 'flying high, lying low'. While we are not using 'lying low' as a marker for women who do not pursue careers, what we are saying is that the curbing of women's aspirations and ambitions through higher education in order for them to not threaten the patriarchal order presents pertinent questions around how higher education is being inculcated into cultural and economic norms. Thus, to 'fly high' can often be viewed as a threat of women's education 
In: Sachdeva, Vivek and Pradhan, Queeny and Venugopalan, Anu, (eds.), Identities in South Asia: Conflicts and Assertions. New Delhi:Routledge.

which can potentially destabilise the ideals of family, young women's respectability, and the balance of the patriarchal order.

\section{Arrangements of Marriage and Migration: Evolving Values of Women's Higher}

\section{Education}

Migration abroad emerged as a significant theme in our exploration of higher education. Punjab is known as a for its steady flow of out-migration to places such as the USA, Canada, the UK, Australia and other parts of the world, particularly over the past six decades. Other studies which have focused on the impacts of global migration on Punjab either through labour migration and subsequent remittances or marriage and transnational kinship practices (Ballard, 1990; Gardner 2006; Charnsley and Shaw 2006). We posit that education and higher education are rapidly becoming new arenas and institutions which are acting as conduits for migration, whether in terms of real strategies and realised plans or in terms of aspirations and imagined futures.

The educational system from primary to higher levels is rapidly expanded and shaped to fit with the demands that globalisation processes are presenting to Punjab. The cultural politics around migration and settlement abroad find a platform through education for the aspirations of young people and their families in strategising their futures (Qureshi and Osella 2013). However, we have found that the globalising influences, including aspirations around migration through education, do not entirely present a liberating picture for young women. Gender 'norms' of the moral economy is being reworked into the educational system rather than being challenged, as the flock of birds annual review poignantly illustrated. However, higher education's recent expansion and intensification in India has meant that it has not been part of this discussion to date. Our study of colleges in rural Punjab highlights how higher education has become a means by which the picture of the value and worth of women's credentials is extending the patriarchal ideology of the family while also intensifying it through institutions, creating certain contradictions around how to contain aspirations meanwhile capitalising upon the education of women for family-building. As stated: 'A daughter is a big responsibility. If she is to go abroad, then she should get married and then go so that we will be relieved of our worries. If she goes abroad to study unmarried, then our worries will never end.'

These concerns or 'worries' are encapsulated through the threat of a young woman migrating abroad to study without the protection of her male kin. Women's autonomy 
presents a threat to the social order, and thus education is commonly understood in this light. A young woman commented on her own experience of visiting relatives (not to migrate) and how local relatives reacted when she returned from her trip: 'Girls want to go abroad to have freedom. They want to escape from the pressures of brothers and parents. I went to Dubai, and I really liked it because no one interfered... But after I returned I went to visit relatives in another village, and I found out that local people had begun to gossip saying that "the girl must have run away.",

Thus, the 'safety' of girls is understood about the threat from unwanted male attention, harassment, or even the threat of daughters forming relationships. However, one of the biggest threats perceived was that of gossip. To avoid 'what people will say,' parents were known to make hasty decisions to marry daughters off to avoid such threats of dishonour via gossip. The classic mode through which gender relations and women's autonomy are commonly understood is through dowry (Sheel 1999). However, dowry as an institution is evolving and changing to the new functions of the family in the economy and therefore, it is not surprising that our study has found that dowry is being reworked through higher education as a means by which the family can negotiate the new terms and social contracts implicit in the establishment of social and kinship relations. The same female teacher who had earlier unquestioningly evoked the paraya dhan (others' property) depiction of girls also made the connection between dowry and education: 'Now, many parents are changing. If they don't have the money, they can't pay for dowries. And then, they value education in the hope of finding a good match for their daughters where they won't have to pay a hefty dowry.'

Her sense of a 'good match' is reliant on the assumption that educated people do not practice dowry. However, as a male teacher commented on how the expansion of education is not changing the attitudes towards gender and the role of dowry: 'Attitudes need to be changed. Education doesn't make a difference.'Perhaps more relevant are how young women themselves are viewing higher education as either a route to escape or challenge prescriptive roles for marriage or as a means by which to gain access to the diaspora through marriage abroad. In both of these scenarios, the notion of the daughter as a burden parents are intent on 'marrying off' lies at the centre of the decision-making process in terms of not wanting to bear the responsibility for the unmarried, 'unprotected' daughter: 'I am doing a dressdesigning course, and then I will go abroad. But if I don't get admission onto a course abroad, 
then I'll get married and go. Parents prefer to get daughters married first so that their husbands will look after and take responsibility for them.'

The emotional and moral responsibility is matched by the economic rationale for not taking a risk or investing finances into daughters' education, as is reflected upon by another female student: 'Some parents think that if you're going to spend money on sending a daughter abroad, then it's better to just spend on the marriage to send her.' The blurring of priorities between educational investment and fulfilment of responsibilities for daughters' marital futures highlight the moral framework within which decisions are made which shape attitudes towards girls' and young women's education. The aspirations to study were not all met by the desire to migrate, though migration emerged as a theme in the context of possibilities and routes after graduation. The determination of the young women to prove to natal relatives that they could achieve despite the barriers and tacit negativity towards women's education was the overarching sense which we found from our focus groups and interviews. Young women in Punjab are also highlighting that there is a strong critique of the rhetoric to promote girls' and women's education while simultaneously discouraging and erecting barriers for them, especially in the face of heightening economic insecurity and the assertion of masculinity through the family and the public sphere. Agarwal (2003) notes how:

In the absence of an effective state social security system, brothers are seen as an important source of security, especially in case of a marital break-up. Cultural constructions of gender, including how a 'good sister' should behave, also discourage women from asserting their rights, as does the emphasis on female seclusion in many areas.

Our study points to this cultural construction in how moral policing is used to curb and regulate young women's access to not only education but also women's autonomy and access to public spaces. As one young woman commented: 'Girls can bring respect and pride to their parents by studying, and we should show them that girls can also do many things in spite of people continually stopping them.'Thus, it is clear from this young woman's statement that, despite structural obstacles and surveillance of their educational experiences, young women are conscious of the policing and the attitudes behind the decision-making around their education. This explains for why the college campuses and students covered in this study were replete with determination by so many young women to achieve in the face of tacit permission or even discrimination against them pursuing studies beyond secondary school. 
In: Sachdeva, Vivek and Pradhan, Queeny and Venugopalan, Anu, (eds.), Identities in South Asia: Conflicts and Assertions. New Delhi: Routledge.

\section{Conclusion}

As this paper has highlighted, the moral economy within which young women's education is valued and permitted is constituted by an objective logic which positions women's educational access and opportunity within the collective concerns of gender norms and the patriarchal household's family-building strategies. Young women are popularly characterised in traditional sayings and songs and understood in their natal homes as paraya dhan (others' property) or chirhiyaa da Chamba (flock of birds). Meanwhile, the moral panic of 'scarce women' and masculine sex ratios or 'surplus men' points to a highly fraught scenario of women being simultaneously viewed as others' property while being in need of protection by one's own natal family. While we have argued that there is little scope for the expansion of higher education to provide liberating effects on women's aspirations due to the pervasiveness of this objective logic, our study highlights how young women and their parents and teachers are subversively answering back to these constructions of their structural vulnerability. In Punjab, a state where there is relatively high per capita income is also a place where grave concerns about young women's education are expressed as a challenge to the social order. However, despite negativity by parents which could deter many young women from pursuing their educational ambitions to 'fly high', many continue to persevere and study under these conditions of tacit negativity about their desires to study further. So while there have been improvements in women gaining access to higher education in Punjab overall, the gendered terrain of attitudes toward women's autonomous ambitions still exists within the objective logic of the family, parental controls, and how parents will be able to negotiate and even contain the impacts of higher education upon their household and family aspirations in light of the potentially transformative impacts of young women's education.

As the colleges in our study have shown, the objective logic is being extended and expanded into educational institutions who appeal to the sentiments of parents, rather than challenging restrictions on young women to maintain the social order of the moral economy and the domestic mode of production. Thus, as we have highlighted, young college women often 'lie low' within the parameters of the patriarchal values while, as an act of persistent defiance or resistance, also project their aspirations and desires to 'fly high' beyond the gendered expectations placed upon them. Young women are challenging this pigeonholing and patronisation in the Chirhiyaa da Chamba depiction both regarding criticisms of their male kin as well as in terms of how they show they are aware of how they can utilise higher education as a means to navigate patriarchal restrictions. However, the limits of this are clear, 
and until women can challenge the material, economic base in asserting themselves beyond being non-inheritors or as paraya dhan, then we are looking at a future of scarce women becoming increasingly controlled, regulated, and commodified in a moral economy in which higher education is providing new and evolving local and global circuits.

\section{Bibliography}

Agarwal, B. (1994) “A Field of One's Own: Gender and Land Rights in South Asia”, Cambridge University Press: Cambridge.

Agarwal, B. (2003) "Gender and Land Rights Revisited: Exploring New Prospects Via the State, Family and Market," Journal of Agrarian Change, 3:1 \& 2, pp. 184-224.

Ballard, R. (1990) Marriage and Kinship: The Differential Effect of Marriage Rules on the Processes of Punjabi Migration to Britain in Clarke, C. Peach, C. and Vertovek, S. (eds.), South Asians Overseas: Contexts and Communities, Cambridge: Cambridge University Press, 1990 pp. $219-249$

Berik, G., Y. Rodgers, and S. Seguino (2009) 'Feminist Economics of Inequality, Development and Growth, Feminist Economics, 15:3, 1-33.

Bourdieu, P. (1992) The Logic of Practice, Polity Press: Cambridge.

Bhalla, M. (2004) "The Land of Vanishing Girls: Sex Selective Abortion in Punjab" in Mohan Rao (ed.) The Unheard Scream: Reproductive Health and Women's Lives in India, pp. 259-278.

Charnsley, K. and A. Shaw (2006) "South Asian Transnational Marriages in Comparative Perspective,” Global Networks, Vol. 6, Issue 4, pp. 331-344.

Chant, S. (2011) Female Headship and the 'Feminisation of Poverty' in Women Worldwide (ed.) Transnational Feminist Perspectives on Women, McGraw Hill Higher Education, New York. 334-336.

Colclough, C. 1982. "The impact of primary schooling on economic development: a review of the evidence." World Development 10 (3): 167-185.

Croll, E. (2002) Endangered Daughters: Discrimination and Development in Asia, Taylor and Francis: London.

Das Gupta, M. and P.N. Mari Bhat (1997) 'Fertility Decline and Increased Manifestation of Sex Bias in India,' Population Studies, 51: 3, 307-315. 
Das Gupta, M. (1995) 'Fertility Decline in Punjab, India: Parallel with Historical Europe, Population Studies, 49, 481-500.

Delphy, C. (1988) "Patriarchy, Domestic Mode of Production, Gender and Class" in Cary Nelson and Lawrence Grossberg, eds. Marxism and the Interpretation of Culture. Urbana: University of Illinois Press, 259-267, translated by D. Leonard.

Delphy, C. (1984) "Close to Home: A Materialist Analysis of Women's Oppression", Translated and edited by D. Leonard, Hutchinson: London.

Elson, D. (1994) 'Micro, meso, macro: Gender and economic analysis in the context of policy reform in I. Baker (ed.) The Strategic Silence: Gender and Economic Policy, Zed: London.

Gardner, Katy (2006) 'The Transnational Work of Kinship and Caring: Bengali-British Marriages in Historical Perspective, Global Networks, 6, 4. Pp. 373-387.

Kapadia, K. (2002) 'Introduction: The Politics of Identity, Social Inequalities and Economic Growth' in K. Kapadia (ed.) The Violence of Development: The Politics of Violence, Gender and Social Inequality in India, pp. 1-40.

Kaur, R. and M. Larsen (2013) "Signs of Change? Sex Ratio Imbalance and Shifting Social Practices in Northern India", Economic and Political Weekly, August 31, vol xlviII no 35.

Mandelbaum, D. (1988) “Women's Seclusion and Men's Honor: Sex Roles in North India”, Bangladesh and Pakistan. Tucson: University of Arizona Press.

Purewal, N. (2010) Son Preference: Sex Selection, Gender and Culture in South Asia, Berg: Oxford.

Purewal, N. 'Disciplining the Sex Ratio: Exploring the Governmentality of Female Feticide in India,' Identities: Global Studies in Culture and Power.

Purewal, N. and N. Hashmi (2014) 'Between Returns and Respectability: Parental Attitudes Towards Girls' Education in Rural Punjab', British Journal of Sociology of Education DOI: DOI: $10.1080 / 01425692.2014 .883274$.

Purewal, N. (2018) 'Sex Selection, Neoliberal Patriarchy and Structural Violence in India,' Feminist Review, 119, Issue 1, pp. 20-38.

Qureshi, Kaveri and Filippo Osella (2013) 'Transnational Schooling in Punjab India: Designer Migrants and Cultural Politics' in L. Bartlett and A. Ghaffar-Kucher (eds.) Refugees, Immigrants and Education in the Global South: Lives in Motion, pp. 99-115, Routledge: London.

Scott, J.C. (1977) The Moral Economy of the Peasant: Rebellion and Subsistence in Southeast Asia, Yale University Press: New Haven.

Sengupta, P., Guha, J. (2002) "Enrolment, Dropout and Grade Completion of Girl Children in West Bengal”, Economic and Political Weekly, Vol.37,no.17,1621-1637. 
In: Sachdeva, Vivek and Pradhan, Queeny and Venugopalan, Anu, (eds.), Identities in South Asia: Conflicts and Assertions. New Delhi:Routledge.

Sharma, U. (1980) Women, Work and Property in North-West India, Tavistock, London. Sheel, R. (1999) The Political Economy of Dowry, Manohar: Delhi. 